\title{
ANALISIS PENENTUAN METODE PENETAPAN TARIF RETRIBUSI RUMAH POTONG HEWAN DALAM PEMENUHAN CAPAIAN TARGET PENDAPATAN ASLI DAERAH DI KOTA BANDUNG
}

\author{
ANALYSIS OF DETERMINATION METHOD FOR DETERMINATION OF \\ ABBATOIR RETRIBUTION TARIFF IN MEETING THE LOCAL REVENUE \\ TARGET IN BANDUNG CITY
}

\author{
Achmad Firman', Andre Revianda Daud, Hermawan² \\ ${ }^{1}$ Departemen Sosial dan Ekonomi Pembangunan Peternakan, Fakultas Peternakan, \\ Universitas Padjadjaran, Jl. Raya Bandung Sumedang Km 21, Jatinangor Sumedang \\ ${ }^{2}$ Departemen Produksi Ternak, Fakultas Peternakan Fakultas Peternakan, \\ Universitas Padjadjaran, Jl. Raya Bandung Sumedang Km 21, Jatinangor Sumedang \\ Email: ahmadpedum@yahoo.com \\ (Diterima 06-12-2019; Disetujui 12-01-2020)
}

\begin{abstract}
ABSTRAK
Penelitian ini bertujuan untuk menganalisis target pendapatan asli daerah (PAD) yang mampu dicapai dari retribusi RPH di Kota Bandung dan model penentuan tarif retribusi yang terbaik yang dapat digunakan untuk pencapaian target PAD. Penelitian ini dilakukan di RPH Ciroyom dan RPH Cirangrang. Data sekunder dari Dinas Pangan dan Pertanian Kota Bandung menjadi data utama untuk dianalisis. Hasil penelitian menunjukkan bahwa target PAD yang ditetapkan di atas Rp 1,5 milyar sangat sulit dicapai apabila sapi yang dipotong di bawah 30.000 ekor per tahun. Adapun model yang terbaik yang mendekati capaian target PAD dan memberikan rasa keadilan yang tinggi adalah model 3 (weight based model).
\end{abstract}

Kata Kunci: sapi potong, tarif, retribusi, RPH

\section{ABSTRACT}

This study aims to analyze the local revenue target (PAD) that can be achieved from the RPH retribution in the Bandung city and the model of determining the best retribution rates that can be used to achieve the PAD target. The location of this research was conducted in Ciroyom RPH and Cirangrang RPH. Secondary data from the Food and Agriculture Office Bandung is the main data to be analyzed. The results showed that the PAD target set above Rp. 1.5 billion is very difficult to achieve if cattle are slaughtered below 30,000 head per year. The best model that approaches the $P A D$ target achievement and gives a high sense of justice is model 3 (weight based model).

Key Words: cattle, tariff, retribustion, abbatoir

\section{PENDAHULUAN}

Daging sapi merupakan sumber protein hewani asal ternak. Permintaan daging sapi di Indonesia relatif lebih tinggi dibandingkan dengan pasokan daging sapi dalam negeri. Dalam rangka mengurangi ketimpangan antara demand dan supply daging sapi di dalam negeri, pemerintah membuka kran impor baik untuk sapi bakalan ataupun daging beku. Pasokan daging sapi dalam negeri hanya mampu memenuhi kebutuhan daging sapi sebesar $30 \%$, sisanya berasal dari impor. Australia merupakan salah satu negara 
pengimpor sapi bakalan dan daging beku terbesar bagi Indonesia.

Isu yang mengemuka saat ini adalah food safety. Keamanan pangan menjadi isu global yang menjadi pusat perhatian karena berkaitan dengan keamanan pangan yang akan dikonsumsi oleh manusia, termasuk daging sapi. Daging sapi berasal dari sapi hidup yang harus diberi perlakuan sebelum menjadi daging dan produk turunannya.

Subadyo (2017) menyatakan bahwa Rumah Pemotongan Hewan (RPH) adalah tempat dan sarana pelayanan masyarakat untuk melakasanakan tempat penyembelihan hewan secara benar, tempat melaksanakan pemeriksaan hewan sebelum dan setelah dipotong serta tempat pemantauan dan surveilans penyakit hewan dan zoonis sehingga daging disediakan menjadi aman, sehat utuh, halal (ASUH). Menurut Tawaf dkk (2013), RPH adalah sebagai lembaga penyedia daging sapi segar dari ternak sapi yang dipotong. Berdasarkan definisi tersebut semakin jelas bahwa RPH adalah sarana dan prasarana yang disiapkan untuk pemotongan ternak yang menghasilkan daging yang ASUH.

Aman artinya daging dan produk lainnya dari hasil pemotongan ternak diperiksa oleh tim kesehatan hewan dan kesehatan masyarakat veteriner dari pengelola RPH untuk memastikan produk daging dan turunannya aman untuk dikonsumsi. Sehat artinya ternak sebelum dipotong (ante mortem) dan setelah dipotong (post mortem) akan diperiksa kesehatannya. Utuh artinya ternak yang akan dipotong tidak memiliki cacat fisik pada saat dipotong. Halal adalah ternak yang dipotong mengikuti syariat Islam tatacara pemotongannya.

Berdasarkan kategori di atas dapat dipastikan produk daging dan turunannya yang dihasilkan RPH sudah memenuhi kriteria aman untuk dikonsumsi. Apabila distribusi daging dan produk turunannya dari RPH ke luar RPH tidak dilakukan dengan baik dapat menyebabkan daging yang dikonsumsi tidak higienis. Oleh karena itu, daging dan produk turunannya yang keluar dari RPH harus menggunakan peralatan khusus agar daging higienis.

Pendirian RPH di suatu daerah harus mengikuti aturan SNI 01-61591999. Standarisasi ini diberikan agar $\mathrm{RPH}$ yang dibangun mampu menghasilkan daging yang ASUH. Demikian juga dengan evaluasi kelayakan RPH akan berpedoman pada SNI standar teknis RPH dan SNI mutu 
karkas dan daging sapi (Aqidawati dan Sutopo, 2017).

Ada beberapa hal yang menyebabkan izin usaha RPH dapat dicabut, yaitu: (1) Kegiatan pemotongan dan/atau penanganan dilakukan di RPH atau UPD yang tidak memiliki izin mendirikan RPH, (2) Melanggar persyaratan teknis tata cara pemotongan dan/atau penanganan daging ternak ruminansia sebagaimana diatur dalam peraturan perundang-undangan,

Tidak melakukan kegiatan pemotongan hewan dalam jangka waktu 6 (enam) bulan berturut-turut setelah izin diberikan, dan (4) Tidak memiliki NKV (Nomor Kontrol Veteriner), setelah jangka waktu yang ditentukan dalam peraturan perundang-undangan (Rudyanto, 2000).

Penyediaan RPH di suatu daerah, misalnya RPH milik pemerintah. adalah tanggung jawab pemerintah daerah karena RPH merupakan salah satu fasilitas publik yang wajib dibangun untuk menjamin pangan yang ASUH. Pembangunan RPH harus didasarkan pada studi kelayakan terlebih dahulu untuk memastikan tingkat kelayakannya. Selanjutnya, penenentuan lokasi yang akan dijadikan tempat RPH. Lokasi yang akan dijadikan RPH sebaiknya jauh dari pemukiman dan memiliki instalasi pengolahan limbah (Lestari, 1994 dalam Asdar, 2014). Kemudian rancang bangun (Detail Engineering Design) RPH dilakukan dalam rangka persiapan pembangunan RPH. Perizinan usaha RPH harus secara sinergi diurus oleh pemerintah daerah yang bersangkutan sehingga RPH yang dibangun tidak memiliki masalah di kemudian harinya.

Pelayanan RPH yang diselenggarakan pemerintah mendapatkan subsidi dari APBD ataupun dari APBN. Subsidi atas aktivitas-aktivitas di RPH ditujukan untuk meringankan beban pengguna (users) dari RPH. Di satu sisi, pemerintah daerah diperkenankan untuk memungut retribusi atas layanan yang dilakukan di RPH. Hal ini didasarkan pada Undangundang No. 28 Tahun 2009 tentang Pajak Daerah dan Retribusi. Berdasarkan ketentuan dalam Pasal 127 pada undangundang tersebut dikatakan bahwa Jenis Retribusi Jasa Usaha adalah: Retribusi Pemakaian Kekayaan Daerah, Retribusi Pasar Grosir dan/atau Pertokoan, Retribusi Tempat Pelelangan, Retribusi Terminal, Retribusi Tempat Khusus Parkir, Retribusi Tempat Penginapan/ Pesanggrahan/Villa, Retribusi Pelayanan Kepelabuhanan, Retribusi Tempat Rekreasi dan Olahraga, Retribusi 
Penyeberangan di Air, dan Retribusi Penjualan Produksi Usaha Daerah. Berdasarkan perundang-undangan tersebut pemerintah daerah diberikan kewenangan untuk memungut retribusi RPH. Retribusi ini bisa menjadi salah satu pemasukan pendapatan bagi daerah.

Menurut Abdul (2001), retribusi adalah sebagai pungutan yang dilakukan oleh pemerintah sebagai akibat adanya kontra prestasi yang diberikan oleh pemerintah daerah atau pembayaran tersebut didasarkan atas prestasi atau pelayanan yang diberikan oleh pemerintah daerah yang langsung dinikmati secara perorangan oleh warna masyarakat dan pelaksanaannya didasarkan atas peraturan yang berlaku.

Kota Bandung merupakan ibu kota Provinsi Jawa Barat yang memiliki 2 (dua) Rumah Potong Hewan (RPH) yang sudah berdiri sejak lama. Dinas Pangan dan Pertanian Kota Bandung diberi tugas untuk mengelola kedua RPH tersebut. Salah satu tugas pokoknya adalah memungut retribusi dari layanan RPH. Kekuatan hukum atas pungutan rertribusi RPH, yaitu UU No. 28 Tahun 2009. Selain itu, Pemerintah Daerah Kota Bandung juga telah memiliki Peraturan Daerah No. 11 Tahun 2012 tentang Penyelenggaraan dan Retribusi Rumah
Potong Hewan. Berdasarkan dua aturan tersebut, Pemda Kota Bandung memungut biaya retribusi atas pelayanan yang diberikan di RPH, seperti penyediaan fasilitas rumah potong hewan ternak, termasuk pelayanan pemeriksaan kesehatan hewan sebelum dan sesudah dipotong.

Adanya pendapatan yang dapat diperoleh dari hasil pungutan retribusi di RPH, Dinas Pangan dan Pertanian Kota Bandung diberi target Pendapatan Asli Daerah (PAD) dari RPH. Selama ini, target PAD yang ditetapkan kepada Dinas Pangan dan Pertanian Kota Bandung belum mampu dipenuhi. Oleh karena itu, tujuan penelitian ini adalah untuk menganalisis trend perkembangan jumlah pemotongan sapi di RPH di Kota Bandung dan menentukan metode yang terbaik yang dapat digunakan untuk penetapan tarif retribusi RPH di Kota Bandung agar target PAD yang ditetapkan dapat tercapai.

\section{METODE PENELITIAN}

Metode yang digunakan dalam penelitian ini adalah metode deskriptif. Metode ini mendeskripsikan berbagai hasil analisis data sekunder yang diperoleh dari berbagai sumber yang terkiat dengan penelitian, seperti Dinas 
Pangan dan Pertanian Kota Bandung, Badan Pusat Statistik Kota Bandung, dan instansi lainnya yang memiliki data yang relevan dengan penelitian ini.

Data yang digunakan dalam penelitian ini adalah data sekunder yang diperoleh dari Dinas Pangan dan Pertanian Kota Bandung maupun melalui situs Badan Pusat Statistik Kota Bandung.

Metode analisis penentuan tarif retribusi yang digunakan dalam penelitian ini adalah sebagai berikut:

\section{a. Metode Activity Based Costing}

Penghitungan biaya pokok untuk jasa pelayanan pemotongan hewan di RPH milik pemerintah dilakukan dengan menggunakan metode activity based costing. Adapun rincian dari biaya-biaya yang dikeluarkan dari seluruh aktivitas di RPH adalah pada Tabel 1.

Tabel 1. Penghitungan Harga Pokok Produksi Pemotongan Hewan (per Tahun)

\begin{tabular}{lll}
\multicolumn{3}{c}{ Pemotongan Hewan (per Tahun) } \\
$\begin{array}{c}\text { Aktivitas } \\
\text { pemotongan } \\
\text { hewan }\end{array}$ & $\begin{array}{c}\text { Cost } \\
\text { Pool } \\
\text { (Rp) }\end{array}$ & $\begin{array}{c}\text { Harga Pokok } \\
\text { Produksi (Rp) }\end{array}$ \\
\hline $\begin{array}{l}\text { Persiapan } \\
\text { (termasuk } \\
\text { pemeriksaan ante } \\
\text { dan post mortem) }\end{array}$ \\
\hline Pemotongan \\
\hline Pengulitan \\
\hline Pengeluaran Jeroan \\
\hline Perecahan \\
\hline Pelayuan \\
\hline Administrasi \\
\hline Total \\
\hline
\end{tabular}

\section{b. Metode Penciptaan Nilai Tambah (Value Added Method)}

Metode penciptaan nilai tambah dalam menentukan tarif retribusi dilakukan dengan menggunakan rumus, dan asumsi-asumsi yang berlaku umum saat ini dengan persamaan (Tawaf, dkk., 2018):

$T=\frac{A N T}{100} \times B B\left(\frac{H N K}{B B}+(P K \times H K)-H H\right)$

Dimana:

- T adalah tarif retribusi RPH dengan satuan rupiah $(\mathrm{Rp})$ per ekor;

- ANT adalah angka normatif tarif dengan satuan absolut (bisa 1; 1,4; atau 2 dan nilai ini bisa hasil trial and error);

- BB adalah bobot badan hidup hewan dengan satuan kilogram $(\mathrm{Kg})$;

- HNK adalah harga pasar Non Karkas dengan satuan ( $R p)$;

- PK adalah Persentase Karkas dengan unit satuan persen (rataan 50\%);

- HK adalah Harga Karkas (Rp/Kg).

- HH adalah Harga Sapi Hidup (Rp/Kg)

\section{c. Metode Penentuan Berdasarkan}

\section{Berat Hidup (Weight Based Model)}

Metode ini menggunakan bobot hidup sebagai dasar penetapan tarif. Semakin berat sapi yang dipotong, maka tarif retribusinya akan semakin besar dan begitu sebaliknya. Metode ini sangat berbeda dengan kedua metode 
sebelumnya karena tarif yang ditetapkan adalah fixed tariff. Sedangkan dengan metode ini, tarif didasarkan pada bobot badan. Adapun formula dari penentuan tarif dengan metode berat hidup adalah sebagai berikut:

$$
\mathrm{T}=\mathrm{BB} / \mathrm{K} \times \mathrm{H}
$$

Dimana:

- T adalah tarif retribusi RPH dengan satuan rupiah $(\mathrm{Rp})$ per ekor;

- BB adalah bobot badan ternak yang ditimbang sebelum dipotong dengan satuan $\mathrm{kg}$;

- $\mathrm{K}$ adalah angka normatif dalam satuan absolut yang ditetapkan sebesar $10 \mathrm{~kg}$;

- H adalah harga yang ditetapkan oleh pengelola untuk mendapatkan kesesuaian dengan imbalan yang akan diperoleh. Angka yang ditetapkan misalnya $\mathrm{Rp}$ 1.000/ekor.

\section{HASIL DAN PEMBAHASAN}

\section{Gambaran Umum}

Perkembangan konsumsi daging di Kota Bandung, khususnya daging ayam dan daging sapi diilustrasikan pada Gambar 1. Berdasarkan gambar tersebut, masyarakat Kota Bandung lebih memilih mengkonsumsi daging ayam dibandingkan dengan daging sapi. Konsumsi daging ayam lebih diminati oleh konsumen karena daging ayam lebih murah dibandingkan dengan daging sapi.

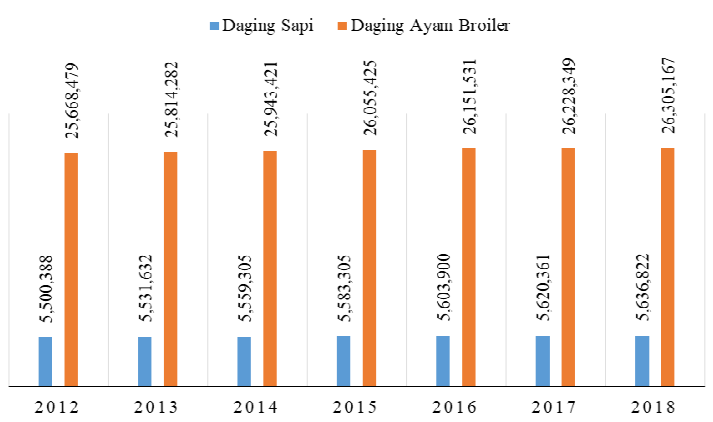

Gambar 1. Perkembangan Konsumsi

Daging Sapi dan Ayam di Kota Bandung (Sumber: BPS Kota Bandung dan asumsi yang diguakan adalah konsumsi daging rata-rata $15 \mathrm{~kg} / \mathrm{kapita}$, dan konsumsi daging ayam $70 \%$ sedangkan daging sapi 15\%)

Di sisi lainnya, menurut data Dinas Pangan dan Pertanian Kota Bandung, demand daging sapi belum mampu dipenuhi dari pasokan daging dari RPH Kota Bandung. Kekurangan pasokan daging sapi dipenuhi dari daging beku impor (lihat Gambar 2).

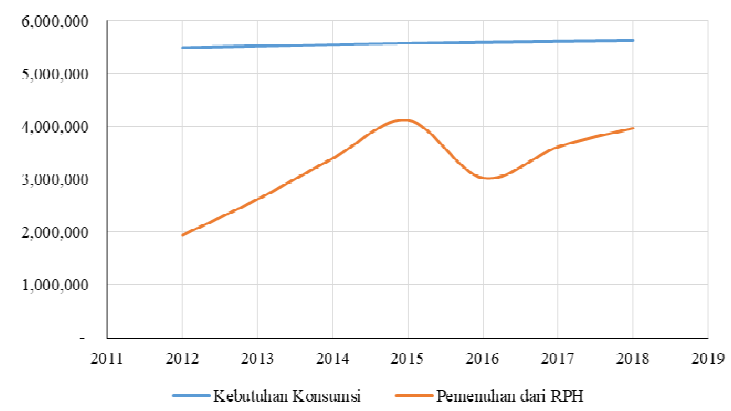

Gambar 2. Kebutuhan Konsumsi dan Pemenuhan Daging Sapi di Kota Bandung

Adapun perkembangan pemotongan sapi di RPH yang ada di Kota Bandung dapat dilihat pada Gambar3. Berdasarkan gambar tersebut 
diperlihatkan bahwa terjadi peningkatan pemotongan sapi dari tahun $2016-2018$.

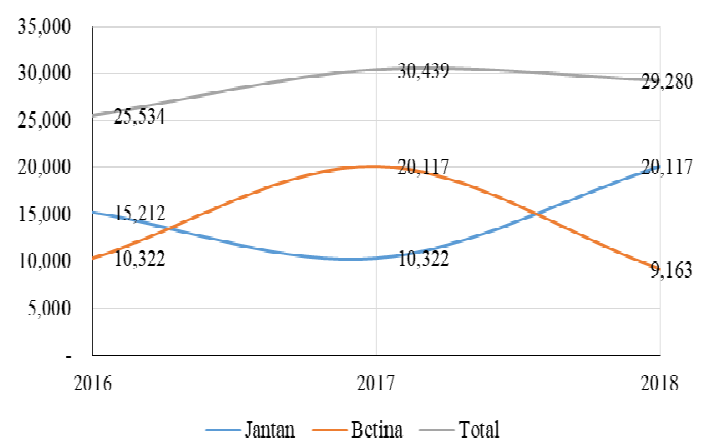

Gambar 3. Perkembangan Pemotongan Sapi Jantan dan Betina di RPH Kota Bandung dari Tahun 2016-2018 (Sumber: Dinas Pertanian dan Ketahanan Pangan Kota Bandung, 2019)

Peningkatan pemotongan ini bisa memberikan indikasi bahwa pelayanan RPH di Kota Bandung memberikan pelayanan yang baik cukup bagi bagi pengguna RPH. Sapi yang dipotong didominasi oleh sapi-sapi hasil penggemukan dari perusahan penggemukan. Pada tahun 2017 terjadi lonjakan sapi betina yang dipotong. Hal ini disebabkan adanya kebijakan dari pemerintah untuk menyertakan $20 \%$ sapi betina dalam setiap impor bakalan.

\section{Perkembangan Target dan Hasil Retribusi RPH}

Perkembangan target dan hasil retribusi RPH di Kota Bandung diperlihatkan pada gambar di bawah ini. Retribusi sapi memberikan sumbangan rata-rata $44,6 \%$ per tahun terhadap target
PAD dari RPH yang ditetapkan, sisanya dipenuhi dari pemotongan babi dan ayam.

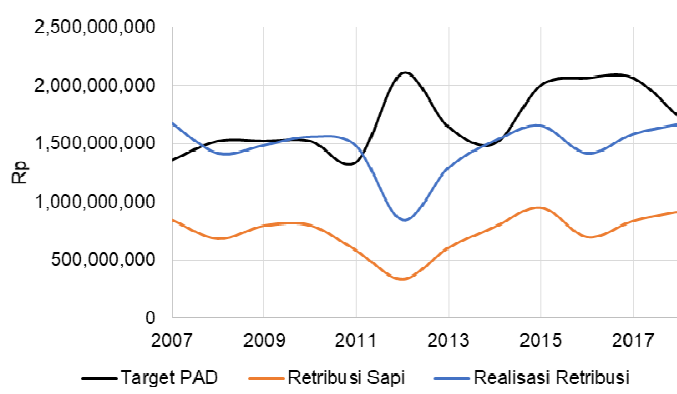

\section{Gambar 4}

Perkembangan Target dan Realisasi Retribusi dari Pemotongan Sapi

(Sumber: Dinas Pangan dan Pertanian Kota Bandung, data diolah)

Berdasarkan data di atas juga diperlihatkan bahwa target PAD dapat dilampaui di tahun 2007, 2010, dan 2013 pada saat target PAD Rp 1,3 milyar - 1,5 milyar. Ketika target PAD ditetapkan di atas $\mathrm{Rp}$ 1,6 milyar, realisasi retribusi tidak mampu mencapai target yang ditetapkan.

\section{Simulasi Penentuan Model Terbaik Penentuan Tarif Retribusi untuk Mencapai Target PAD}

Ada 3 model yang dapat digunakan untuk penentuan penetapan tarif retribusi, yaitu:

\section{Model 1: Activity Based Model}

Model penentuan tarif ini didasarkan pada keseluruhan biaya pelayanan yang disiapkan di RPH. Hasil penelitian Fakultas Peternakan Unpad 
(2013) menunjukkan bahwa biaya yang dibutuhkan untuk membiayai pelayanan RPH di Kabupaten Bandung dapat dilihat pada Tabel 2. Menurut tabel tersebut, biaya yang dibutuhkan untuk pengelolaan RPH adalah Rp 799.421.110. Apabila rata-rata jumlah pemotongan sapi per tahun adalah 25.000 ekor sapi, maka tarif retribusi dapat ditentukan sebesar $\mathrm{Rp}$ 31.977/ekor atau dibulatkan menjadi $\mathrm{Rp}$ 32.000/ekor.

Tabel 2. Gambaran Proporsi Biaya Menurut Sumberdaya di RPH Pemerintah

\begin{tabular}{llrr}
\hline No & \multicolumn{1}{c}{ Aktivitas } & \multicolumn{1}{c}{ Nilai } & \multicolumn{1}{c}{ \% } \\
\hline 1 & Infrastruktur & $298,630,500$ & 37.36 \\
2 & Air & $58,255,200$ & 7.29 \\
3 & Listrik & $22,535,410$ & 2.82 \\
4 & Tenaga Kerja & $79,570,000$ & 9.95 \\
5 & Peralatan & & \\
& - Belanja Barang & $284,055,000$ & 35.53 \\
& • Belanja Modal & $56,375,000$ & 7.05 \\
& Jumlah & $799,421,110$ & 100.00 \\
& Pemotongan Sapi & 25.000 & \\
& per tahun (ekor) & & \\
& Tarif Retribusi & 32.000 & \\
& (Rp/Ekor) & (dibulatkan) & \\
\hline
\end{tabular}

Sumber: Data tahun 2013 untuk RPH di wilayah Kabupaten Bandung (observasi), Fakultas Peternakan UNPAD, 2013.

\section{Model 2: Value Added Model}

Model penentuan tarif ini dikembangkan oleh Tim Peneliti Fakultas Peternakan Unpad dalam penentuan tarif retribusi. Menurut formula yang dikembangkan, yaitu:

$T=\frac{A N T}{100} \times B B\left(\frac{H N K}{B B}+(P K x H K)-H H\right)$

Berdasarkan formula tersebut dapat dihitung tarif retribusi sebagai berikut:
$T=\frac{1,5}{100} \times 400\left(\frac{1950000}{400}+(50 \% \times 88000)-43000\right)$

Yaitu:

- ANT =1,5; yang artinya beban kontribusi sebesar $1,5 \%$ dari nilai tambah berubahnya bentuk sapi menjadi karkas;

- BB adalah bobot hidup hewan (digunakan sapi) dengan rata-rata berat $400 \mathrm{Kg}$

- HNK adalah harga pasar Non Karkas (Jeroan yang biasa dimakan (edible oval), $850.000+$ Harga Kaki, 200.000 + Harga Kulit, $400.000+$ Harga Kepala, 500.000), yaitu Rp 1.950.000

- PK adalah Persentase Karkas sebesar minimal $50 \%$, untuk sapi

- HK adalah Harga Karkas, yaitu Rp $88.000 / \mathrm{Kg}$

- HH adalah Harga Hidup sapi, yaitu Rp $43.000 / \mathrm{Kg}$

Dengan menggunakan asumsi-asumsi diatas, diperoleh tarif retribusi untuk RPH adalah Rp 35.250 per ekor, bila dibulatkan menjadi Rp 35.000.

\section{Model 3: Weight Based Model}

Model penetuan tarif ini didasarkan pada berat sapi sebelum dipotong. Artinya, sapi harus ditimbang dulu sebelum dipotong. Model ini membuat tarif retribusi tidak fixed seperti dua model di atas tetapi didasarkan pada berat 
hidup sapi sebelum dipotong.

Berdasarkan formula:

$\mathrm{T}=\mathrm{BB} / \mathrm{K} \times \mathrm{H}$

Bedasarkan rumus tersebut dapat dihitung, jika berat sapi adalah $400 \mathrm{~kg}$ sebelum dipotong, maka nilai tarif retribusinya adalah

$\mathrm{T}=(400 \mathrm{~kg} / 10 \mathrm{~kg}) \times \mathrm{Rp} 1000 /$ ekor $=$ Rp 40.000/ekor

Berdasarkan ketiga formula tersebut, maka dapat dihitung pencapai target PAD didasarkan ketiga model tersebut yang dimulai dari tahun 20072018. Adapun hasil analisis diilustrasikan pada Gambar 5.

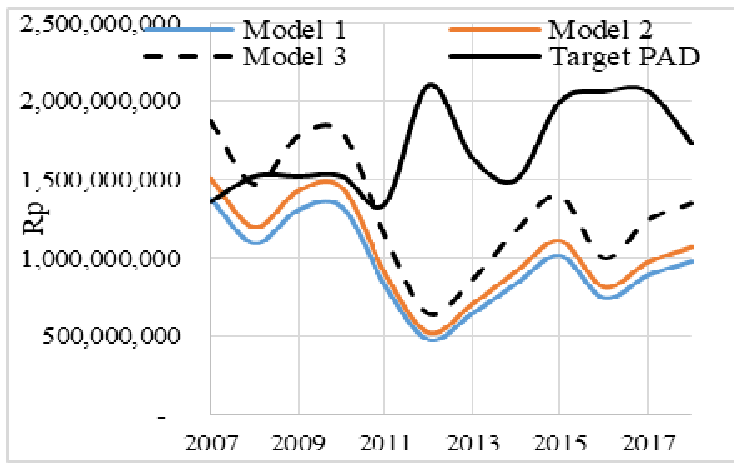

Gambar 5. Simulasi Penentuan Model Tarif Retribusi Terbaik dalam Mencapai Target PAD

Berdasarkan hasil analisis dari ketiga model tersebut dapat dilihat bahwa apabila target PAD ditetapkan di atas Rp 1,5 milyar, PAD tidak dapat dicapai hanya dengan komoditas sapi, tetapi jika PAD ditetapkan di bawah Rp 1,5 milyar maka target PAD tersebut dapat dicapai dan retribusi dari sapi potong memberikan kontribusi terbesar bagi capaian tersebut.

Gambar 5 juga memperlihatkan bahwa model 3 mendekati capaian target PAD. Model ini memberikan rasa keadilan dengan penentuan tarif didasarkan pada berat hidup, semakin berat sapi maka tarif pun menjadi besar. Ketiga model sangat dipengarhui oleh jumlah sapi yang dipotong di RPH. Semakin banyak sapi yang dipotong, maka berkorelasi positif dengan peningkatan retribusi.

\section{KESIMPULAN}

Berdasar hasil uraian di atas dapat disimpulkan sebagai berikut:

1. Target PAD yang ditetapkan di atas Rp 1,5 milyar sangat sulit dicapai berdasarkan data historis pemotongan sapi di RPH di Kota Bandung

2. Model 3 (weight based model) adalah model dengan pendekatan terbaik karena penentuan tarif dari model ini didasarkan pada berat sapi sebelum dipotong sehingga dapat memberikan rasa keadilan.

\section{DAFTAR PUSTAKA}

Abdul Halim. 2001. Manajemen Keuangan Daerah. Yogyakarta: Penerbit Bunga Rampai.

Aqidawati, E.F, dan W Sutopo. 2017. Kajian Tekno Ekonomi Perbaikan 
Rumah Potong Hewan untuk Mendukung Penyediaan Daging Sapi di Pasar Tradisional yang Aman, Sehat, Utuh dan Halal: Studi Kasus. Prosiding Seminar dan Konferensi Nasional IDEC, Surakarta, 8-9 Mei 2017: 396-405.

Asdar, Z. 2014. Analisis Proses Pengelolaan Pemotongan Sapi dan Kebau di Rumah Potong Hewan Tamangapa Kecamatan Manggala Makassar. Fakultas Peternakan, Universitas Hasanudin.

Dinas Pangan dan Pertanian Kota Bandung. 2019. Laporan Perkembangan Pemotongan dan Penerimaan Asli Daerah Kota Bandung. Dinas Pangan dan Pertanian Kota Bandung.

Fakultas Peternakan Unpad. 2013. Penentuan Tarif Retribusi RPH di Kabupaten Bandung. Fakultas Peternakan Unpad.
Rudyanto, M.D. 2000. Persyaratan Mendirikan Rumah Potong Hewan. Fakultas Kedokteran Hewan, Universitas Udayana.

Subadyo, A. Tutut. 2017. Pengelolaan dampak pembangunan Rumah Potong Hewan Ruminansia di Kota Batu. Jurnal ABDIMAS Unmer Malang. Vol 2 (2).

Tawaf, R. Obin Rachmawan dan Andre Daud. 2013. Revitalisasi Rumah Pemotongan (RPH) Milik Pemerintah di Jawa Barat. Fakultas Peternakan Universitas Padjadjaran.

Tawaf, R., L Herlina, dan A Fitriani. 2018. Metode Analisis Biaya Potong Pada Rumah Potong Hewan di Kabupaten Bandung. Jurnal Ilmu Ternak, 18(1):34-40. DOI:10.24198/jit.v18i1.18163. 